\title{
PEMBANGUNAN APLIKASI SISTEM PAKAR DIAGNOSIS PENYAKIT KARIES PADA GIGI MANUSIA
}

\author{
Dini Silvi Purnia \\ Manajemen Informatika \\ AMIK BSI Tasikmalaya \\ Jalan Tanuwijaya No.4, Empangsari Tawang Tasikmalaya \\ dinisilvi35@yahoo.co.id
}

\begin{abstract}
Teeth are part of the tools of mastication on the digestive system in the human body, dental disease often suffered by nearly all of Indonesia's population is dental caries, Dental caries is also becoming the major problems of oral health. Dental caries is an infectious disease caused by demineralization of enamel and dentin are closely associated with the consumption of cariogenic foods. The occurrence of dental caries due to the role of caries-causing bacteria found in the mouth streptococci group collectively called Streptococcus mutans. Dental caries is a disease caused by demineralization of enamel and dentin. Disorders in Dental Caries often occur due to various causes, among other things because of bacteria, food and drink a lot of sugars, oral hygiene, etc. Knowledge of the Human Dental caries disease is needed to resolve the issue quickly and appropriately, Most people consider trivial when teeth are not clean them in a state that can be very dangerous unwittingly In his Dental Health, For the treatment should not be done arbitrarily. Thus, eventually the thought of how to cope with the disease and caring for Dental Caries without having to go direct consultation with a doctor or specialist. The development of information technology and computer and Internet use is already well known by the public. can be used to help a good idea ini.Sehingga makes authors want to help to create an expert system application that can perform diagnosis of skin diseases that can also display other information required. With the ease of application of this expert system can be used as a guide for mendekteksi easily caries disease and the type of caries disease and its prevention that occur in human teeth.
\end{abstract}

Keyword : Caries, Desease, Expert, System, Teeth

\begin{abstract}
Abstrak - Gigi merupakan bagian dari alat pengunyahan pada sistem pencernaan dalam tubuh manusia, Penyakit gigi yang sering diderita oleh hampir semua penduduk Indonesia ialah karies gigi. Karies Gigi juga menjadi permasalah utama Pada kesehatan gigi dan mulut. Karies gigi merupakan penyakit infeksi yang disebabkan oleh demineralisasi email dan dentin yang erat hubungannya dengan konsumsi makanan yang kariogenik. Terjadinya karies gigi akibat peran dari bakteri penyebab karies yang terdapat pada golongan Streptokokus mulut yang secara kolektif disebut Streptokokus mutans. Karies gigi merupakan penyakit yang disebabkan oleh demineralisasi email dan dentin. Gangguan pada Karies Gigi sering terjadi karena berbagai faktor penyebab, antara lain karna bakteri, makanan dan minuman yang banyak mengadung gula, kebersihan gigi dan mulut dan lain-lain Pengetahuan tentang penyakit Karies pada Gigi Manusia sangat dibutuhkan untuk mengatasi masalah tersebut secara cepat dan tepat. Sebagian orang menganggap sepele ketika Gigi mereka dalam keadaan tidak bersih sehingga tanpa disadari bisa sangat berbahaya Pada Kesehatan Gigi nya, Untuk itu pengobatannya tidak boleh dilakukan secara sembarangan. Dengan demikian, akhirnya timbul pemikiran bagaimana cara mengatasi penyakit dan merawat Karies Gigi tanpa harus mendatangi atau konsultasi langsung dengan dokter spesialis. Perkembangan teknologi informasi dan komputer serta internet yang sudah cukup dikenal penggunaannya oleh masyarakat. dapat digunakan untuk membantu ide baik ini.Sehingga membuat penulis ingin ikut membantu dengan membuat aplikasi sistem pakar yang dapat melakukan diagnosa penyakit kulit yang juga dapat menampilkan informasi lain yang diperlukan. Dengan kemudahan aplikasi sistem pakar ini dapat digunakan sebagai pedoman untuk mendekteksi dengan mudah penyakit karies dan jenis penyakit karies serta pencegahan nya yang terjadi pada gigi manusia.
\end{abstract}

Kata Kunci : $\quad$ Gigi, Karies, Pakar, Penyakit, Sistem 


\section{PENDAHULUAN}

Kesehatan gigi merupakan bagian integral dari kesehatan pada umumnya. Selain itu gigi merupakan salah satu organ pencernaan yang berperan penting dalam proses pengunyahan makanan, sehingga pemeliharaan kesehatan gigi penting dilakukan (Depkes RI, 1999). Hasil laporan morbiditas 2001, menunjukkan bahwa kesehatan gigi dan mulut di Indonesia masih menjadi keluhan masyarakat yaitu sekitar $60 \%$, diantaranya karies gigi dan penyakit periodontal (Depkes $\mathrm{RI}, 2002)$.

Gigi merupakan bagian dari alat pengunyahan pada sistem pencernaan dalam tubuh manusia.Masalah utama kesehatan gigi dan mulut ialah karies gigi. Penyakit gigi yang sering diderita oleh hampir semua penduduk Indonesia ialah karies gigi.Riset kesehatan dasar (Riskesdas) tahun 2007 menyebutkan bahwa prevalensi karies aktif di Indonesia sebesar 46,5\%. Menurut data Riskesdas tahun 2007, provinsi Sulawesi Utara memiliki indeks DMF-T 5.01.Karies gigi merupakan penyakit infeksi yang disebabkan oleh demineralisasi email dan dentinyang erat hubungannya dengan konsumsi makanan yang kariogenik. Terjadinya karies gigi akibat peran dari bakteri penyebab karies yang terdapat pada golongan Streptokokus mulut yang secara kolektif disebut Streptokokus mutans.

Gangguan pada Karies Gigi sering terjadi karena berbagai faktor penyebab, antara lain karna bakteri, makanan dan minuman yang banyak mengadung gula, kebersihan gigi dan mulut dan lain-lain Pengetahuan tentang penyakit Karies pada Gigi Manusia sangat dibutuhkan untuk mengatasi masalah tersebut secara cepat dan tepat. Sebagian orang menganggap sepele ketika Gigi mereka dalam keadaan tidak bersih sehingga tanpa disadari bisa sangat berbahaya Pada Kesehatan Gigi nya, Untuk itu pengobatannya tidak boleh dilakukan secara sembarangan. Dengan demikian, akhirnya timbul pemikiran bagaimana cara mengatasi penyakit dan merawat Karies Gigi tanpa harus mendatangi atau konsultasi langsung dengan dokter spesialis.

Saat ini berbagai keluhan tentang karies pada Gigi sering dialami oleh masyarakat yang berobat. Pasien ditanya dan diperiksa mulut dan giginya agar dapat diketahui penyakitnya sehingga dokter dapat melakukan diagnosa yang kemudian ditindak lanjuti dengan tahap pengobatan. Proses diagnosa kelainan ini biasanya memakan waktu lebih lama dari pada proses pemberian resep dokter untuk pengobatannya. Dengan semakin banyaknya pasien yang datang ke Rumah Sakit atau puskesmas dengan beberapa keluhan yang sama, proses diagnosa yang dilakukan dokterpun sama pada hampir semua pasiennya dan cukup memakan waktu lama untuk membuat para pasien mengantri, oleh karena itu dokter berinisiatif untuk membantu masyarakat agar dapat melakukan diagnosa sendiri terhadap gangguan ataupun keluhan terhadap kesehatan gigi.

Perkembangan teknologi informasi dan komputer serta internet yang sudah cukup dikenal penggunaannya oleh masyarakat dapat digunakan untuk membantu ide baik ini.Sehingga membuat penulis ingin ikut membantu dengan membuat aplikasi komputer untuk membuat sistem pakar yang dapat melakukan diagnosa penyakit karies Pada Gigi Manusia yang juga dapat menampilkan informasi lain yang diperlukan

\section{KAJIAN LITERATUR}

\section{Sistem Pakar}

Sistem pakar dibuat hanya pada domain pengetahuan tertentu untuk suatu kepakaran tertentu yang mendekati kemampuan manusia disalah satu bidang saja. Sistem pakar mencoba mencari penyelesaian yang memuaskan, yaitu sebuah penyelesaian yang cukup bagus agar pekerjaan dapat berjalan walaupun itu bukan penyelesaian yang optimal.

Sistem pakar sebagai sebuah program yang difungsikan untuk menirukan pakar manusia harus bisa melakukan hal-hal yang dapat dikerjakan oleh seorang pakar. Untuk membangun sistem yang seperti itu maka komponen-komponen yang harus dimiliki adalah sebagai berikut (Giarratano dan riley,2005):

1. Antarmuka Pengguna (User Interface)

2. Basis Pengetahuan (Knowledge Base)

3. Mekanisme Inferensi (Inference machine)

4. Memori kerja (Working Memory)

Sedangkan untuk menjadikan sistem pakar menjadi lebih menyerupai seorang pakar yang berinteraksi dengan pemakai, maka dilengkapi dengan fasilitas berikut:

1. Fasilitas Penjelasan (Explanation Facility)

2. Fasilitas Akuisisi Pengetahuan (Knowledge Acquisition Facility)

Turban dalam Arhami (2005b:11) menyatakan bahwa " konsep dasar dari suatu sistem pakar mengandung beberapa unsur/elemen, yaitu keahlian, ahli, pengalihan 
keahlian, inferensi, aturan dan kemampuan menjelaskan."

Terdapat tiga orang yang terlibat dalam lingkungan sistem pakar menurut Turban dalam Arhami (2005c:12-13), yaitu:

1. Pakar, adalah orang yang memiliki pengetahuan, khusus pendapat pengalaman dan metode, serta kemampuan untuk mengaplikasikan keahliannya tersebut guna menyelesaikan masalah.

2. Knowledge engineer (perekayasa sistem), adalah orang yang membantu pakar dalam menyusun area permaslahan dengan menginterprestasikan dan mengintegrasikan jawaban-jawaban pakar atas pertanyaan yang diajukan, menggambarkan analogi, mengajukan counter example dan menerangkan kesulitan-kesulitan konseptual.

3. User (Pemakai), sistem pakar memiliki beberapa pemakai, yaitu: pemakai bukan pakar, pelajar, pembangun sistem pakar yang ingin meningkatkan dan menambahkan basis pengetahuan, dan pakar.

Menurut Turban dalam Arhami (2005d:13) menyatakan bahwa " Sistem pakar disusun oleh dua bagian utama, yaitu lingkungan pengembangan (development environment) dan lingkungan konsultasi (consultation environment)."

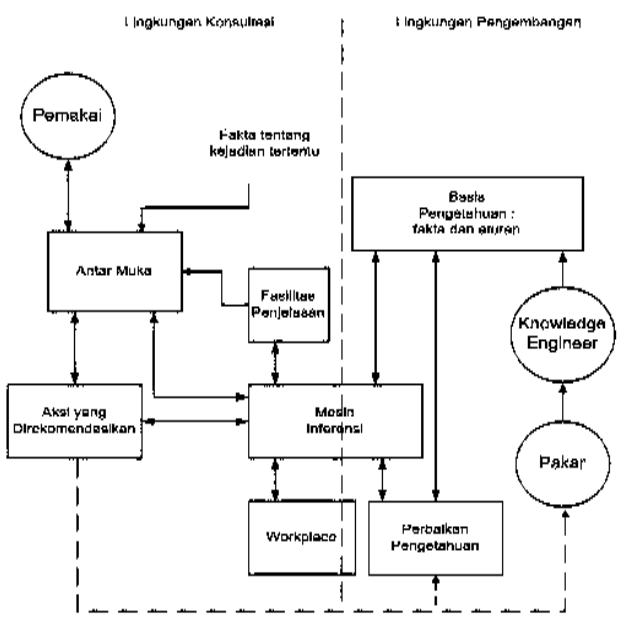

Gambar 1

Susunan sistem Pakar

Sumber :Arhami (2005d:13)

Pada gambar di atas menjelaskan bahwa, sistem pakar disusun menjadi dua bagian utama, yaitu: pertama, lingkungan pengembangan (development environment), kedua lingkungan konsultasi. Di bawah ini akan dijelaskan secara ringkas komponenkomponen yang membentuk sistem pakar.

1. Antarmuka pengguna (user interface) Antarmuka pengguna merupakan mekanisme yang digunakan oleh pengguna dan sistem pakar untuk berkomunikasi. Antarmuka menerima informasi dari pemakai dan mengubahnya ke dalam bentuk yang dapat diterima oleh sistem. Selain itu antarmuka menerima informasi dari sistem dan menyajikannya ke dalam bentuk yang dapat dimengerti oleh pemakai.

2. Basis Pengetahuan

Basis pengetahuan mengandung pengetahuan untuk pemahaman, formulasi, dan menyelesaikan maslah. Komponen ini disusun atas dua elemen dasar, yaitu fakta dan aturan. Fakta merupakan informasi tentang obyek dalam area permasalahan tertentu, sedangkan aturan merupakan informasi tentang cara bagaimana memperolah fakta baru dari fakta yang telah diketahui.

3. Akuisisi Pengetahuan

Akuisisi pengetahuan adalah akumulasi, transfer dan transformasi keahlian dalam menyelesaikan masalah dari sumber pengetahuan ke dalam program computer. Dalam tahap ini knowledge engineer berusaha menyerap pengetahuan untuk selanjutnya ditransfer ke dalam basis pengetahuan. Pengetahuan berasal dari pakar, dilengkapi dengan buku, basis data, laporan penelitian dan pengalaman pemakai.

4. Mesin Inferensi (Inference Engine)

Komponen ini mengandung mekanisme pola pikir dan penalaran yang digunakan oleh pakar dalam menyelesaikan suatu masalah.

\section{Runut Maju (forward chaining.)}

Runut maju merupakan metode pencarian yang memulai proses pencarian dari sekumpulan data atau fakta, dari fakta-fakta tersebut, kemudian dari aturan-aturan tersebut diperoleh suatu kesimpulan. Runut maju memulai proses pencarian dengan data sehingga strategi ini disebut juga data-driven. Penalaran maju atau forward chaining merupakan suatu strategi pengambilan keputusan yang dimulai dari bagian sebelah kiri (IF lebih dahulu). Dengan kata lain, penalaran dimulai dari fakta terlebih dahulu untuk menguji kebenaran hipotesis. 


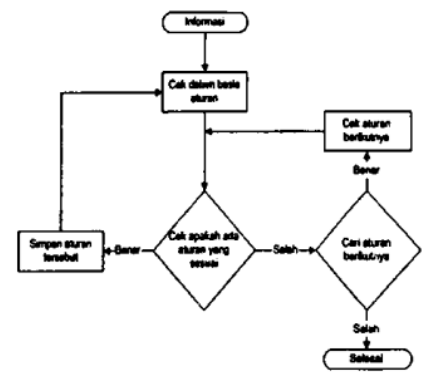

Gambar 2

Runut Maju

\section{Struktur Pohon}

Secara sederhana pohon bisa didefinisikan sebagai kumpulan elemen yang salah satu elemennya

disebut akar (root), dan sisa elemen yang lain (yang disebut simpul) terpecah menjadi sejumlah himpunan yang saling tidak berhubungan satu sama lain yang disebut subpohon (subtree), atau juga disebut cabang. Jika melihat pada setiap subpohon, maka subpohon inipun juga mempunyai akar dan sub-subpohonnya masing-masing. Tingkat suatu simpul ditentukan dengan pertama kali menentukan akar sebagai bertingkat. Selain tingkat, juga dikenal istilah derajat dari suatu simpul.Derajat suatu simpul dinyatakan sebagai banyaknya anak atau turunan dari simpul tersebut.

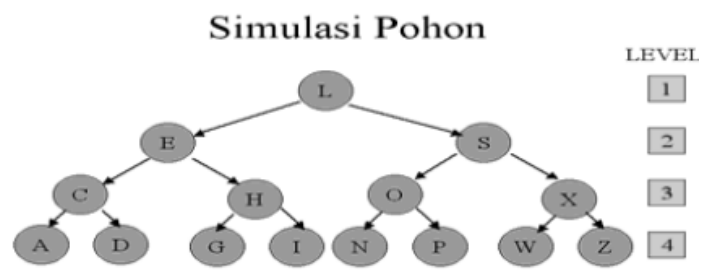

\section{Gambar 3}

Struktur Pohon

Sumber :Wayan shandyasa (2011)

\section{Metode Waterfall}

Nama model ini sebenarnya adalah "Linear Sequential Model". Model ini sering disebut dengan "classic life cycle" atau model waterfall. Model ini adalah model yang muncul pertama kali yaitu sekitar tahun 1970 sehingga sering dianggap kuno, tetapi merupakan model yang paling banyak dipakai didalam Software Engineering (SE). Model ini melakukan pendekatan secara sistematis dan urut mulai dari level kebutuhan sistem lalu menuju ke tahap analisis, desain, coding, testing atau verification, dan maintenance. Disebut dengan waterfall karena tahap demi tahap yang dilalui harus menunggu selesainya tahap sebelumnya dan berjalan berurutan.

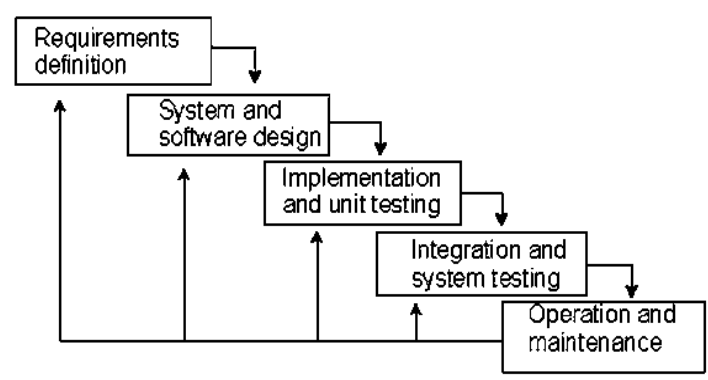

Gambar 4

Model Waterfall

Sumber : Pressman (2008:29)

Berikut adalah penjelasan dari tahap-tahap yang dilakukan di dalam model ini:

1. System Information Engineering and

Modeling

Permodelan ini diawali dengan mencari kebutuhan dari keseluruhan sistem yang akan diaplikasikan ke dalam bentuk software. Hal ini sangat penting, mengingat software harus dapat berinteraksi dengan elemen-elemen yang lain seperti hardware, database, dan lain-lain. Tahap ini sering disebut dengan Project Definition.

1. Software Requirements Analysis

Proses pencarian kebutuhan diintensifkan dan difokuskan pada software. Untuk mengetahui sifat dari program yang akan dibuat, maka para software engineer harus mengerti tentang domain informasi dari software, misalnya fungsi yang dibutuhkan, user interface, dsb. Dari 2 aktivitas tersebut (pencarian kebutuhan sistem dan software) harus didokumentasikan dan ditunjukkan kepada pelanggan.

2. Design

Proses ini digunakan untuk mengubah kebutuhan-kebutuhan diatas menjadi representasi ke dalam bentuk "blueprint" software sebelum coding dimulai. Desain harus dapat mengimplementasikan kebutuhan yang telah disebutkan pada tahap sebelumnya. Seperti 2 aktivitas sebelumnya, maka proses ini juga harus didokumentasikan sebagai konfigurasi dari software.

3. Coding

Untuk dapat dimengerti oleh mesin, dalam hal ini adalah komputer, maka desain tadi harus diubah bentuknya menjadi bentuk yang dapat dimengerti oleh mesin, yaitu ke dalam bahasa pemrograman melalui proses coding. Tahap ini merupakan implementasi dari tahap design yang secara teknis nantinya dikerjakan oleh programmer. 
4. Testing atau Verification

Sesuatu yang dibuat haruslah diujicobakan. Demikian juga dengan software. Semua fungsi-fungsi software harus diujicobakan, agar software bebas dari error, dan hasilnya harus benarbenar sesuai dengan kebutuhan yang sudah didefinisikan sebelumnya.

5. Maintenance

Pemeliharaan suatu software diperlukan, termasuk di dalamnya adalah pengembangan, karena software yang dibuat tidak selamanya hanya seperti itu. Ketika dijalankan mungkin saja masih ada errors kecil yang tidak ditemukan sebelumnya, atau ada penambahan fitur-fitur yang belum ada pada software tersebut. Pengembangan diperlukan ketika adanya perubahan dari eksternal perusahaan seperti ketika ada pergantian sistem operasi, atar perangkat lainnya.

\section{Penyakit Karies Gigi}

Karies gigi merupakan penyakit infeksi yang disebabkan olehdemineralisasi email dan dentin yang erat hubungannya dengan konsumsi makanan yang kariogenik. Terjadinya karies gigi akibat peran dari bakteri penyebab karies yang terdapat pada golongan Streptokokus mulut yang secara kolektif disebut Streptokokus mutans.

Gangguan pada Karies Gigi sering terjadi karena berbagai faktor penyebab, antara lain karna bakteri, makanan dan minuman yang banyak mengadung gula, kebersihan gigi dan mulut dan lain-lain Pengetahuan tentang penyakit Karies pada Gigi Manusia sangat dibutuhkan untuk mengatasi masalah tersebut secara cepat dan tepat. Sebagian orang menganggap sepele ketika Gigi mereka dalam keadaan tidak bersih sehingga tanpa disadari bisa sangat berbahaya Pada Kesehatan Gigi nya, Untuk itu pengobatannya tidak boleh dilakukan secara sembarangan. Dengan demikian, akhirnya timbul pemikiran bagaimana cara mengatasi penyakit dan merawat Karies Gigi tanpa harus mendatangi atau konsultasi langsung dengan dokter spesialis.

\section{METODE PENELITIAN}

\section{Metode Pengumpulan Data}

Metode pengumpulan data terdiri dari pengumpulan data primer dan sekunder

1. Pengumpulan Data Primer

Pengumpulan data dilakukan dengan melakukan wawancara langsung kepada seorang ahli atau pakar dalam hal ini dokter gigi dan mulut

2. Pengumpulan Data Sekunder

Mengumpulkan data dengan cara membaca dan mempelajari buku-buku, makalah-makalah, artikel-artikel dan bahanbahan dari internet yang sesuai dengan topik yang sedang dibahas.

\section{Metode Pengembangan Sistem}

Metode pengembangan sistem pakar yang akan digunakan adalah metode pengembangan sistem pakar. Metode ini merupakan salah satu model yang menggambarkan tahap-tahap pengembangan perangkat lunak sistem pakar. Tahapan pengembangan sistem pakar (Durkin, 1994), dapat dilihat pada gambar 5 .

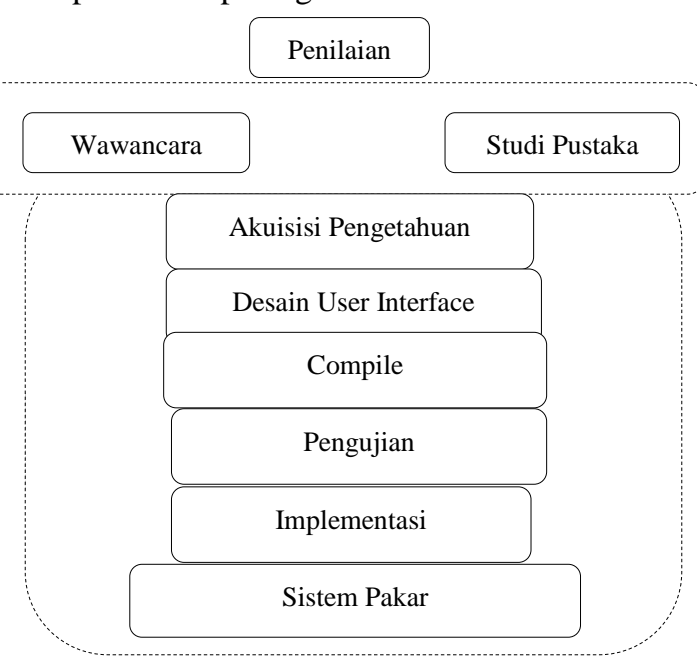

\section{Gambar 5}

Tahap Pengembangan Sistem Pakar

a) Penilaian.

Yaitu proses untuk menentukan kelayakan dan justifikasi atas permasalahan yang akan diambil. Setelah proyek pengembangan dianggap layak dan sesuai dengan tujuan, maka selanjutnya ditentukan fitur-fitur penting dan ruang lingkup proyek serta sumberdaya yang dibutuhkan. Sumber pengetahuan yang diperlukan diidentifikasi dan ditentukan persyaratan-persyaratan proyek.

b) Akuisisi Pengetahuan.

Merupakan proses untuk mendapatkan pengetahuan tentang permasalahan yang akan dibahas dan digunakan sebagai panduan dalam pengembangan. Pengetahuan ini digunakan untuk memberikan informasi tentang permasalahan yang menjadi bahan acuan dalam mendesain system pakar.

c) Desain

Berdasarkan pengetahuan yang telah didapatkan dalam proses akuisisi pengetahuan, maka desain antarmuka maupun teknik 
penyelesaian masalah dapat diimplementasikan kedalam sistem pakar. Dalam tahap desain ini, seluruh struktur dan organisasi dari pengetahuan harus ditetapkan dan dapat direpresentasikan kedalam sistem.

d) Pengujian

Tahap ini dimaksudkan untuk menguji apakah system pakar yang dibangun telah sesuai dengan tujuan pengembangan maupun kesesuaian kinerja sistem dengan metode penyelesaian masalah yang bersumber dari pengetahuan yang sudah didapatkan. Apabila dalam tahap ini terdapat bagian yang harus dievaluasi maupun dimodifikasi maka hal tersebut harus segera dilakukan agar sistem pakar dapat berfungsi sebagaimana tujuan pengembangannya.

e) Implementasi

Tahap implementasi sistem pakar mencakup pemrograman pengetahuan kedalam komputer, perbaikan struktur dan penambahan pengetahuan baru. Hasil tahap ini berupa prototype basis

pengetahuan.

\section{PEMBAHASAN}

\section{Algoritma Sistem Pakar}

Dalam perancangan sistem pakar diagnosa penyakit Karies Gigi ini metode yang digunakan adalah metode forward chaining. Metode ini merupakan strategi pencarian yang memulai proses pencarian dari sekumpulan data atau fakta, dari data-data tersebut dicari suatu kesimpulan yang menjadi solusi dari permasalahan yang dihadapi. Algoritma pengujian sistem pakar penyakit Karies Gigi.

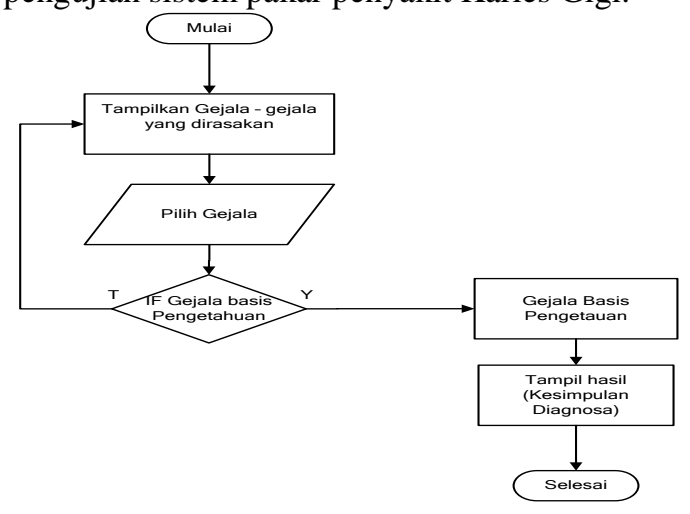

Gambar 6

Tahap Pengembangan Sistem Pakar

\section{Tabel Pakar}

Tabel pakar merupakan fakta-fakta yang diperoleh dari pakar, ilmu pengetahuan, penelitian dan pengalaman-pengalaman mereka dalam mengidentifikasi gejala penyakit kelainan Darah. Data-data yang telah di kumpulkan sebagai berikut:

Tabel 1

Tabel Pakar

\begin{tabular}{|l|c|c|c|c|}
\hline \multirow{2}{*}{ KODE } & \multicolumn{4}{|c|}{ PENYAKIT } \\
\hline & K001 & K002 & K003 & K004 \\
\hline G001 & $\mathrm{X}$ & & & \\
\hline G002 & $\mathrm{X}$ & & & \\
\hline G003 & & $\mathrm{X}$ & & \\
\hline G004 & & $\mathrm{X}$ & $\mathrm{X}$ & $\mathrm{X}$ \\
\hline G005 & & & $\mathrm{X}$ & \\
\hline G006 & & & $\mathrm{X}$ & \\
\hline G007 & & & & $\mathrm{X}$
\end{tabular}

Tabel 2

Tabel Gejala

\begin{tabular}{|c|l|}
\hline KODE GEJALA & \multicolumn{1}{|c|}{ NAMA GEJALA } \\
\hline G001 & Ada Lubang Hitam di permukaen Gigi \\
\hline G002 & Tidal sakit spabila di ketulk \\
\hline G003 & Ngilu Kalsu kena sir dingin \\
\hline G004 & Salkit spabila diketuk \\
\hline G005 & Bolong di darah permulkan Alar \\
\hline G006 & Tununnya Gusi \\
\hline G007 & Giginya ada bintil putih dipermulkaen gigi \\
\hline
\end{tabular}

Tabel 3

Tabel Kesimpulan Penyakit

\begin{tabular}{|c|l|}
\hline Kode Rule & \multicolumn{1}{|c|}{ Nama Penyakit } \\
\hline K001 & Karies Superfisialis \\
\hline K002 & Karies Media \\
\hline K003 & Karies Profund a \\
\hline K004 & Karies Insipiens \\
\hline
\end{tabular}

\section{Rule-rule pada Pakar}

Data yang ada mengenai jenis-jenis penyakit Darah sering dialami, terlebih dahulu dibuat menjadi satu aturan, sehingga dalam penyelesaian masalah akan lebih mudah untuk dilakukan pelacakan atau penelusuran. Untuk mendapat solusi yang terbaik dari beberapa gejala - gejala yang dialami pasien, maka penulis membuat knowledge base atau rule base sistem pakar yang biasanya ditulis dalam bentuk jika-maka (IFTHEN) adalah sebagai berikut :

\section{Rule 1}

Jika Ada Lubang Hitam di permukaan Gigi Dan Tidak sakit apabila di ketuk Maka jenis penyakit Darah yang di derita adalah Karies Superfisialis 
Rule 2

Jika Ngilu Kalau kena air dingin Dan Sakit apabila diketuk Maka jenis penyakit Darah yang di derita adalah Karies Media

\section{Rule 3}

Jika Bolong di daerah permukaan Akar Dan Turunnya Gusi Dan Sakit apabila diketuk Maka jenis penyakit Darah yang di derita adalah Karies Profunda

\section{Rule 4}

Jika Giginya ada bintik putih dipermukaan gigi Dan Tidak sakit apabila di ketuk Maka jenis penyakit Darah yang di derita adalah Karies Insipiens

\section{Pohon Pakar Keputusan}

Pengambilan keputusan dari sistem pakar akan lebih mudah apabila dibentuk terlebih dahulu sebuah pohon keputusan. Diagram keputusan merupakan gambaran secara sederhana permasalahan dan pemecahannya.

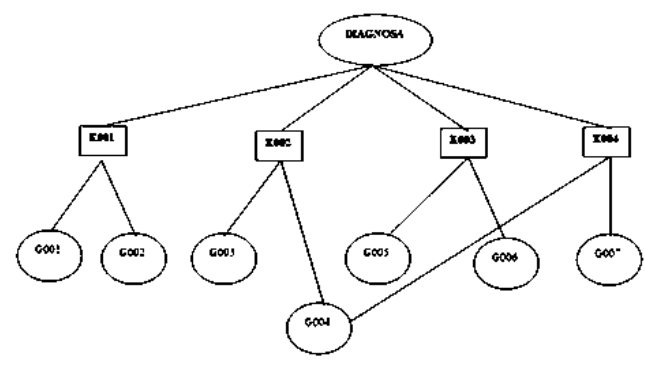

Gambar 7

Pohon Pakar Keputusan

E. Deskripsi Alur Sistem

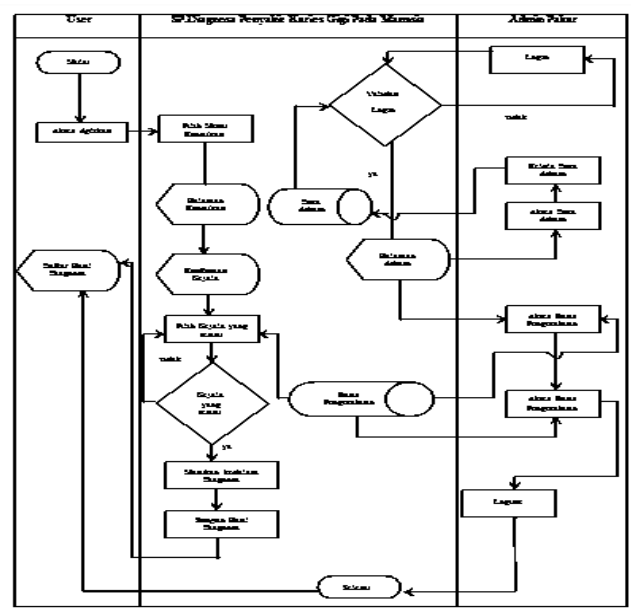

Gambar 8

Deskripsi Alur Sistem
F. ERD (Entity Relationship Diagram)

Bentuk ERD yang digunakan pada sistem pakar diagnosa penyakit karies pada Gigi Manusia ini sebagai berikut:

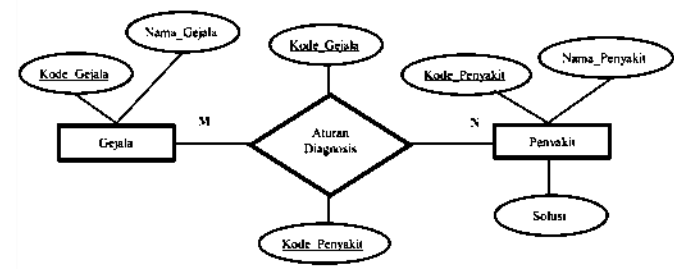

Gambar 9

Entity Relationship Diagram

G. Struktur Menu

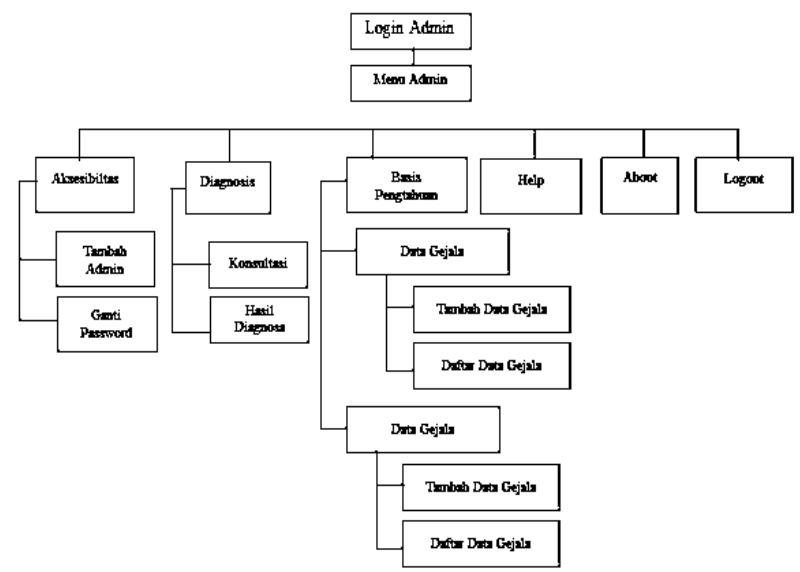

Gambar 10

Struktur Menu Admin

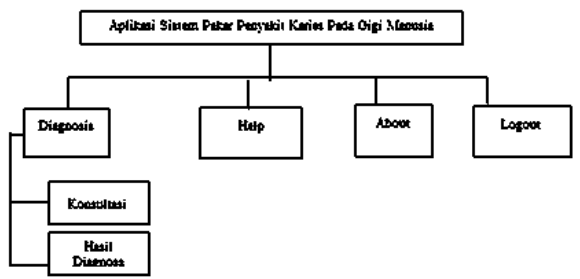

Gambar 11

Struktur Menu User

H. Tampilan Menu Utama

1.Tampilan Menu Utama Sistem

Tampilan utama sistem yang dihasilkan aplikasi sistem pakar untuk diagnosis penyakit Karies pada Gigi Manusia 


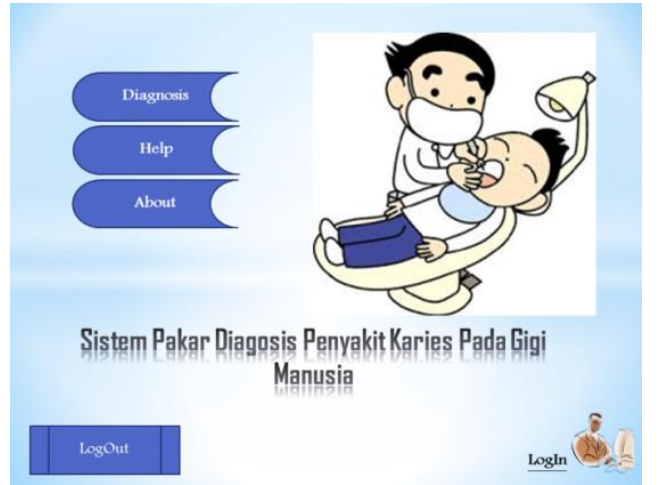

Gambar 12

Tampilan Menu Utama Sistem

2. Tampilan Menu Utama User

Tampilan menu utama user yang dihasilkan aplikasi sistem pakar untuk diagnosis penyakit Karies pada Gigi Manusia

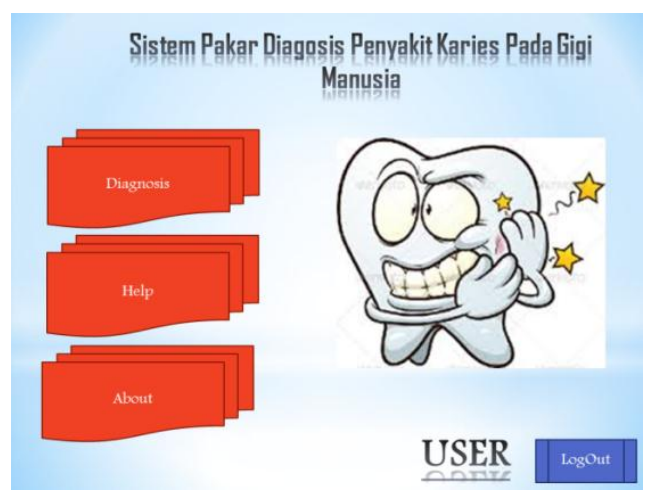

\section{Gambar 13 \\ Tampilan Menu Utama User}

3. Tampilan Menu Utama Admin

Tampilan menu utama admin yang dihasilkan aplikasi sistem pakar untuk diagnosis penyakit Karies pada Gigi Manusia

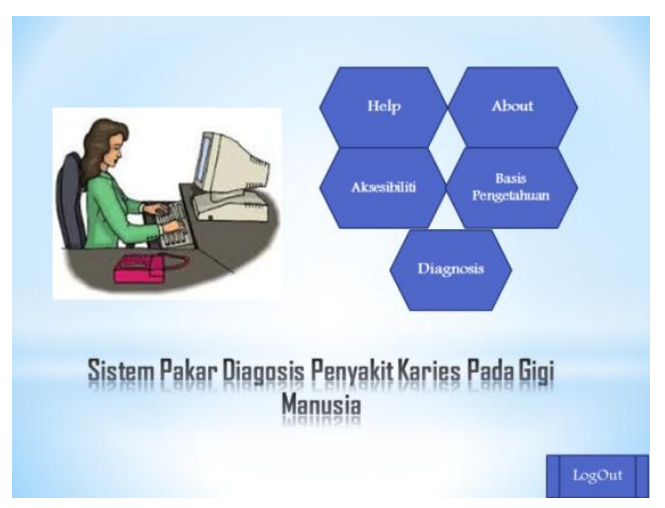

Gambar 14

Tampilan Menu Utama Admin

\section{Hasil Pengujian}

Hasil pengujian yang telah dilakukan dengan menggunakan metode pengujian Black Box, dapat dilihat pada tabel 4 .

\section{Tabel 4}

Tabel Hasil Pengujian Menggunakan Black Box

\begin{tabular}{|c|c|c|c|}
\hline \multicolumn{4}{|c|}{ Pengujian Sistem Pakar Unnuk Diagnosis Penyakit Kanies Pada Gigg Manusia } \\
\hline Itren Pengujim & Deshipgsi & Jenis Pengrgijm & Kesimpulan \\
\hline Kossillari Uie & Memerikaz Konstlati & Bide $\mathrm{BOX}$ & Ditumima \\
\hline Login Admin & Meneviksa Log̣n Ademin & Bald Box & Diterima \\
\hline Tambah Dax Gejala & 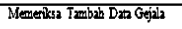 & Bidck Box & $\begin{array}{ll}\text { Diterima } \\
\end{array}$ \\
\hline Ubah Data Gejala & 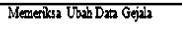 & Bald Box & 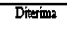 \\
\hline Hapus Dan Gógala & 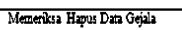 & Bidd Box & Dierima \\
\hline Tambat Data Petyylatit & 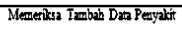 & B2idt Box & Dintima \\
\hline Ubah Dan Praylatot & 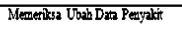 & Bick BOx & Dinerima \\
\hline Hapus deat Peayzlatit & Mementisa Hipus dat Pengyalit & Balck Box & Diterima \\
\hline Gant Password & Menentusz Gami Password & Bicts Box & Diterima \\
\hline
\end{tabular}

\section{PENUTUP}

\section{Kesimpulan}

Setelah mempelajari, membahas dan menganalisis pengetahuan sistem pakar untuk diagnosis penyakit Karies Pada gigi manusia, maka diambil beberapa kesimpulan sebagai berikut :

1. Sistem pakar diagnosis penyakit karies gigi manusia ini sangat diperlukan dan dapat dijadikan sebagai asisten yang cukup cerdas untuk membantu pekerjaan staf/ pegawai di Puskesmas atau rumah sakit serta dapat meningkatkan pemahaman pasien dalam mengetahui dengan benar gejala penyakit Karies Pada Gigi Manusia.

2. Menggunakan forward chaining sebagai metode inferensinya, aplikasi sistem pakar ini memudahkan user dalam melakukan proses konsultasi, dimana hasil diagnosis berupa nama penyakit serta solusi pengobatannya yang sesuai dengan data gejala yang di inputkan oleh user.

3. Pengujian dengan menggunakan metode Black box bahwa pada aplikasi sistem pakar bisa berjalan dengan baik dan bisa menghasilkan output yang diharapkan serta bisa dipakai pada tahap konsultasi.

\section{REFERENSI}

[1] Nurlaela, Fetty. (2013). Sistem Pakar untuk mendeteksi penyakit gigi pada manusia, Volume 10 No 4 (ISSN : 1979-9330).

[2] Worotitjan, Indry. Mintjelungan, Christy N.Gunawan,Paulina.(2013).Jurnal e-Gigi. Pengalaman Karies Gigi Serta Pola 
Makan dan Minum Pada Anak Sekolah Dasar di Desa Kiawi Kecamatan Kawangkoan Utara, Volume 1.

[3] Nurzaman, Destiani Dini, Dhamiri Dhami Johar. (2012). Pembangunan Aplikasi Sistem Pakar untuk Diagnosis Penyakit Gigi dan Mulut Pada Manusia. Jurnal Algoritma, Vol. 09 No. 122012 (ISSN : 2302-7339).

[4] Purnia, Dini Silvi. (2014). Sistem Pakar Berbasis Web Untuk Diagnosa Penyakit Karies Pada Gigi Manusia Studi Kasus: Rumah Sakit Umum Daerah Tasikmalaya. 